\title{
Penerapan Layanan Konseling Pada Siswa Yang Melanggar Tata Tertib Sekolah Di Madrasah Aliyah Darunnah Lumajang
}

\author{
Moh. Muafi Bin Thohir \\ Institut Agama Islam Syarifuddin Lumajang \\ Email :muafilumajang@gmail.com
}

\begin{abstract}
The background problem of this study is the existence of violations of the rules of conduct committed by students in Madrasah Aliyah Darunnajah Lumajang school, on the other hand, guidance and counseling services in schools are entrusted to BK teachers to help and guide students to better and prevent students from doing more violation. This research is focused on the application of counseling services to students who violate school rules. While the objectives to be achieved in this study were to determine the Application of Counseling Services to Students Who Violated School Rules in Madrasah Aliyah Darunnajah Lumajang. The research method used in this research is descriptive qualitative research. The data collection method used is the method of observation, interview methods and documentation methods. The results of this study are that after getting counseling from counseling teachers, students no longer repeat violations of school rules, whether they are minor, moderate, or severe violations. The results of the guidance and counseling applied by the BK teacher is that students become better at obeying school rules and regulations. The services used by BK teachers are individual counseling services, group counseling, and information services. It is expected that in implementing the guidance and counseling service by the BK teacher, students can obey the school rules set by the school without being forced to and with self-awareness.
\end{abstract}

\section{Key words: Counseling, Rules of Conduct, Violations}

\section{PENDAHULUAN}

Ulama erat berhubungannya dengan sesuatu gelar yang menekankan pemuliaan dan pengakuan, yang diberikan masyarakat secara sukarela kepada orang muslim tertentu sebagai pimpinan agama atau tokoh masyarakat. Dikalangan masyarakat Islam tradisional Jawa, 
Pendidikan merupakan komponen utama dalam menentukan tingkat kemajuan suatu bangsa. Pendidikan dapat mengarahkan kepada masa depan bangsa, baik itu baik ataupun buruk, itu ditentukan oleh pendidikan kita saat ini. Jika pendidikan saat ini teroptimalkan dan dimanfaatkan fungsinya secara baik maka kemajuan bangsa, masa depan bangsa yang cerah bukan lagi hanya sekedar impian belaka, tapi sudah menjadi kepastian yang terwujud. ${ }^{1}$ Undang-undang sistem pendidikan nasional no. 20 tahun 2003 pasal 3 dinyatakan bahwa pendidikan nasional berfungsi mengembangkan kemampuan dan membentuk watak serta peradaban bangsa, bertujuan untuk berkembangnya potensi peserta didik agar menjadi manusia yang beriman dan bertakwa kepada Tuhan Yang Maha Esa, berakhlak mulia, sehat, berilmu, cakap, kreatif, mandiri, dan menjadi warga Negara yang demokratis serta bertanggung jawab. ${ }^{2}$

Perkembangan zaman yang pesat dan terus menerus menawarkan perubahan, telah menuntut individu secara sadar atau tidak untuk meningkatkan kualitas hidupnya.Permasalahan demi permasalahan turut mengiringi perubahan yang terjadi disetiap sisi kehidupan.Permasalahan kehidupan sangatlah kompleks.Berawal dari permasalahan peribadi, bahkan masalah kehidupan secara luas.Hal ini memaksa individu untuk segera diselesaikan, karena secara sadar atau tidak, individu selalu berupaya untuk keluar dari masalah yang tengah dihadapinya.Beragam permasalahan yang dihadapi oleh individu sebaiknya tidak dibiarkan menumpuk di dalam pikirian. Mengabaikan masalah hingga akhirnya tidak mendapatkan penanganan yang tepat akan menimbulkan tekanan yang sangat mengganggu dan mengancam kesehatan fisik dan mental. Menurunnya tingkat kekebalan tubuh, susah tidur, pikiran kacau, mudah marah, dan efeksi negatif lainnya hanyalah contoh kecil efek samping dari masalah yang dihadapi individu. ${ }^{3}$

\footnotetext{
${ }^{1}$ Wardati \& Mohammad Jauhar, Implementasi Bimbingan \& Konseling di Sekolah,(Surabaya: Prestasi Pustakarya, 2011), .52

${ }^{2}$ Ibid, Op., cit, 129

3 Namora Lumongga Lubis, Memahami Dasar-Dasar Konseling, (Medan: Kencana Prenada Media Group, 2011), 1-2
} 
Setiap individu akan berkembang menurut polanya masing-masing dan hal ini merupakan tantangan bagi setiap konselor untuk mengenali dan memahaminya. Memahami dan mengerti individu merupakan tugas pokok seorang konselor agar dalam melaksanakan tugasnya dapat membantu individu mencapai perkembangan dirinya seoptimal mungkin.Setiap individu mempunyai berbagai aspek yang dapat mempengaruhi perkembangan dirinya, baik fisik maupun psikis. Aspek-aspek pribadi individu yang harus dikenal dan dipahami oleh konselor antara lain perkembangan individu, perbedaan individu, kebutuhan individu, penyesuaian individu, dan kepribadian individu. ${ }^{4}$

Pada masa anak-anak, sebelum menginjak masa remaja, sekolah merupakan tempat pendidikan yang diidealkan oleh mereka, para guru merupakan tokoh yang sangat penting dalam kehidupan mereka karena selain tokoh intelektual, guru juga merupakan tokoh otoritas bagi para peserta didiknya.Oleh karena itu, tidak jarang anak-anak lebih percaya, lebih patuh, bahkan lebih takut kepada guru dari pada kepada orang tua. Posisi guru semacam ini sangat strategis apa bila digunakan untuk pengembangan emosi anak melalui penyampaian materi-materi yang positif dan konstruktif. ${ }^{5}$

Kehadiran di sekolah merupakan perluasan lingkungan sosialnya dalam proses sosialisasinya dan sekaligus merupakan faktor lingkungan baru yang sangat menantang atau bahkan mencemaskan dirinya. Para guru dan teman-teman sekelas membentuk suatu sistem yang kemudian menjadi semacam lingkungan norma bagi dirinya. Selama tidak ada pertentangan, selama itu pula anak tidak akan mengalami kesulitan dalam menyesuaikan dirinya. Sebagaimana dalam lingkungan keluarga, lingkungan sekolah juga dituntut menciptakan iklim kehidupan sekolah yang kondusif bagi perkembangan sosial remaja.Sekolah merupakan salah satu lingkungan tempat remaja hidup dalam kesehariannya.Sebagaimana keluarga, sekolah juga memiliki potensi memudahkan atau menghambat perkembangan hubungan sosial

4 Susilo Rahardjo \& Gudnanto, Pemahaman individu teknik nontes, (Kudus: Kencana Prenadamedia Group,2013), 10

5 Mohammad Ali \& Mohammad Asrori, Psikologi Remaja, Perkembangan Peserta Didik, (Jakarta: PT Bumi Aksara, 2004), 71 
remaja.Diartikan sebagai fasilitator, iklim kehidupan lingkungan sekolah yang kurang positif dapat menciptakan hambatan bagi perkembangan hubungan sosial remaja.Sebaliknya, sekolah yang iklim kehidupannya bagus dapat memperlancar atau bahkan memacu perkembangan hubungan sosial remaja. ${ }^{6}$ Pada dasarnya setiap individu menghadapi permasalahan dalam hidupnya dalam jenis dan intensitas yang berbeda.Di antara masalah individu tersebut, beberapa masalah dapat dipecahkan sendiri tanpa intervensi konselor/guru, sedangkan masalah lainnya masih belum bisa diselesaikan sehingga mereka membutuhkan bantuan konselor. Pada umumnya masalah emosi konseli yang cara penyelesaiannya membutuhkan bantuan konseling adalah: (1) masalah kecewa, (2) masalah frustasi, (3) masalah kecemasan, (4) masalah stress, (5) masalah depresi, (6) masalah konflik, (7) masalah ketergantungan. Di antara masalah ini dapat dialami konseli secara bersamaan, misalnya di samping konseli mengalami masalah kecewa, ia juga menderita masalah frustasi, kecemasan, begitu juga masalah yang lain. ${ }^{7}$

\section{PERMASALAHAN}

Permasalahan-permasalahan yang terjadi di sekolah MA.DA Jerowaru tidak terlepas dari kenakalan siswa siswi yang sering melanggar peraturan di sekolah seperti datang terlambat, bolos sekolah, merokok di kantin, dan keluar pada saat jam pelajaran.Dalam menangani masalah tersebut, guru BK berperan aktif dalam memberikan penanganan serta pelayanan kepada siswa dan menindak lanjuti masalah yang terjadi pada sisawa yang sering melanggar tata tertib sekolah guna memberikan pelajaran dan etika yang baik, dan memberikan pandangan agar tidak sering melakukan pelangaran-pelangaran disekolah. ${ }^{8}$

Melihat permasalahan di atas maka peneliti tertarik meneliti bagaimana sebenarnya penerapan bimbingan konseling dilakukan oleh guru BK di sekolah

6 Ibi'd, Op., cit, 96

7 Hartono \& Boy Soedarmadji, Psikologi Konseling, (Surabaya: Kencana Prenada Media Group, 2012), 83

8 Hasil wawancara dengan guru BK di Madrasah Aliya Darunnajah lumajang. 
Madrasah Aliya Darul Aitam Jerowaru.Untuk itu peneliti mengangkat judul "Penerapan Bimbingan dan Konseling Pada Siswa Yang Melanggar Tata Tertib Sekolah di Madrasah Aliyah Darunnajah Lumajang ". 


\section{METODE}

Metode penelitian yang digunakan dalam penelitian ini adalah penelitian kualitatif deskriptif. Adapun metode pengumpulan data yang dilakukan adalah metode observasi, metode wawancara dan metode dokumentasi. Di dalam metode yang digunakan tersebut yang dicari adalah apa bentuk-bentuk pelanggaran tata tertib yang dilakukan oleh siswa di Madrasah Aliyah Darunnajah lumajang dan bagaimana penerapan layanan bimbingan konseling pada siswa yang melanggar tata tertib sekolah di Madrasah Aliyah Darunnajah lumajang.

\section{PEMBAHASAN}

\section{Bimbingan Konseling}

Menurut Smith, dalam McDaniel, Bimbingan adalah bantuan yang diberikan kepada individu-individu guna membantu mereka memperoleh pengetahuan dan keterampilan-keterampilan yang di perlukan dalam membuat pilihan-pilihan, rencanarencana, dan interpretasi-interpretasi yang diperlukan untuk menyesuaikan diri yang baik. ${ }^{9}$

Menurut Division of Conseling Psychology, Konseling merupakan suatu proses untuk membantu individu mengatasi hambatan-hambatan perkembangan dirinya, dan untuk mencapai perkembangan optimal kemampuan pribadi yang dimilikinya, proses tersebut dapat terjadi setiap waktu. ${ }^{10}$

Sejalan dengan perkembangannya konsepsi bimbingan dan konseling, maka tujuan bimbingan dan konseling pun mengalami perubahan, dari sederhana sampai ke yang lebih komperhensif. Perkembangan itu dari waktu ke waktu dapat dilihat pada kutipan dibawah ini:

9 Prayitno \& Erman Amti, Dasar-Dasar Bimbingan dan Konseling, (Jakarta: PT.Rineka Cipta, 1994), 93

10 Ibid, Op., cit , 99 
1. Untuk membantu individu membuat pilihan-pilihan, penyesuaian-penyesuaian dan interpretasi-interpretasi dalam hubungannya dengan situasi-situasi tertentu.

2. Untuk membantu orang-orang menjadi insan yang berguna, tidak hanya sekedar mengikuti kegiatan-kegiatan yang berguna saja.

Dengan memperhatikan butir-butir tujuan bimbingan dan konseling sebagaimana tercantum dalam rumusan-rumusan tersebut, tampak bahwa tujuan umum bimbingan dan konseling adalah untuk membantu individu memperkembangkan diri secara optimal sesuai dengan tahap perkembangan dan predisposisi yang dimilikinya. ${ }^{11}$

Dalam kelangsungan perkembangan dan kehidupan manusia, berbagai pelayanan diciptakan dan diselenggarakan.Masing- masing pelayanan itu berguna dan memberikan manfaat untuk memperlancar dan memberikan dampak positif sebesarbesarnya terhadap kelangsungan perkembangan dan kehidupan itu, khususnya dalam bidang tertentu yang menjadi fokus pelayanan yang dimaksud.

Fungsi bimbingan dan konseling ditinjau dari kegunaan atau manfaat, ataupun keuntungan-keuntungan apa yang diperoleh melalui pelayanan tersebut. Fungsi-fungsi itu banyak dan dapat dikelompokkan menjadi empat fungsi pokok, yaitu:

1. Fungsi Pemahaman; Dalam fungsi pemahaman, kegunaan, manfaat, atau keuntungan-keuntungan apakah yang diberikan oleh layanan bimbingan dan konseling? Jasa yang diberikan oleh pelayanan adalah berkenaan dengan pemahaman, yaitu klien dengan berbagai permasalahannya, dan dengan tujuantujuan konseling. Pemahaman yang perlu dihasilkan oleh pelayanan bimbingan dan konseling adalah pemahaman tentang diri klien beserta permasalahannya oleh klien sendiri dan oleh pihak-pihak yang akan membantu klien, serta pemahaman tentang lingkungan klien oleh klien.

2. Fungsi Pencegahan; Ada suatu slogan yang berkembang dalam bidang kesehatan, yaitu "mencegah lebih baik daripada mengobati”.Slogan ini relevan dengan bidang bimbingan dan konseling yang sangat mendambakan sebaiknya

${ }^{11}$ Ibid, Op., cit , 112 
individu tidak mengalami suatu maslah. Apabila individu tidak mengalami proses perkembangannya dengan baik, dan kegiatan kehidupannya pun dapat terlaksana tanpa ada hambatan yang berarti. Dalam dunia kesehatan mental "pencegahan" didefinisikan sebagai upaya mempengaruhi dengan cara yang positif dan bijaksana lingkungan yang dapat menimbulkan kesulitan atau kerugian sebelum kesulitan atau kerugian itu benar-benar terjadi.

3. Fungsi Pengentasan; Orang yang mengalami masalah itu dianggap berada dalam suatu keadaan yang tidak mengenakkan sehingga perlu diangkat atau dikeluarkan dari bendanya yang tidak mengenakkan.la perlu dientas dari keadaan yang tidak disukainya itu. Upaya yang dilakukan untuk mengatasi permasalahn itu adalah upaya pengentasan melalui pelayanan bimbingan dan konseling.

4. Fungsi Pemeliharaan dan Pengembangan; Fungsi pemeliharaan berarti memelihara segala sesuatu yang baik yang ada pada diri individu, baik hal itu merupakan pembawaan maupun hasil-hasil perkembangan yang telah dicapai selama ini.Pemeliharaan yang demikian itu adalah pemeliharaan yang membangun, pemeliharaan yang memperkembangkan. ${ }^{12}$

Prinsip merupakan paduan hasil kajian teoritik dan telaah lapangan yang digunakan sebagai pedoman pelaksanaan sesuatu yang dimaksudkan. Dalam pelayanan bimbingan dan konseling prinsip-prinsip yang digunakannya bersumber dari kajian filosofis, hasil-hasil penelitian dan pengalaman praktis tentang hakikat manusia, perkembangan dan kehidupan manusia dalam konteks sosial budayanya, pengertian, tujuan, fungsi dan proses penyelenggaraan bimbingan dan konseling.

Van hoose (1969) mengemukakan bahwa:

1. Bimbingan didasarkan pada keyakinan bahwa dalam diri tiap anak terkandung kebaikan-kebaikan, seperti pribadi mempunyai potensi dan pendidikan hendaklah mampu membantu anak memanfaatkan potensinya itu.

2. Bimbingan didasarkan pada ide bahwa setiap anak adalah unik, seseorang anak berbeda dari yang lain.

12 Ibid, Op., cit , 196 
3. Bimbingan merupakan bantuan kepada anak-anak dan pemuda dalam pertumbuhan dan perkembangan mereka menjadi pribadi-pribadi yang sehat.

4. Bimbingan merupakan usaha membantu mereka yang memerlukannya untuk mencapai apa yang menjadi idaman masyarakat dan kehidupan umumnya.

5. Bimbingan adalah pelayanan, unik yang dilaksanakan oleh tenaga ahli dengan latiha-latihan khusus, dan untuk melaksanakan pelayanan bimbingan diperlukan minat pribadi khusus pula.

Semua butiran yang dikemukakan oleh Van Hoose itu benar, tetapi butir-butir tersebut belum merupakan prinsip-prinsip yang jelas aplikasinya dalam praktek aplikasi bimbingan dan konseling.

Bernard \& Fullmer, mengemukakan bahwa rumusan prinsip-prinsip bimbingan dan konseling pada umumnya berkenaan dengan sasaran pelayanan, masalah klien, tujuan dan proses penanganan masalah, program pelayanan, penyelenggaraan pelayanan. ${ }^{13}$

Jenis-jenis Layanan Bimbingan dan Konseling.

1. Layanan Orientasi; Layanan orientasi adalah layanan bimbingan yang dilakukan untuk memperkenalkan siswa baru dan atau seseorang terhadap lingkungan yang baru dimasukinya.

2. Layanan Informasi; Secara umum, bersama dengan layanan orientasi bermaksud memberikan pemahaman kepada individu-individu yang berkepentingan tentang berbagai hal yang diperlukan untuk menjalani suatu tugas atau kegiatan, atau untuk membentuk arah suatu tujuan atau rencana yang dikehendaki.

3. Layanan Penempatan dan Penyaluran; Individu sering mengalami kesulitan dalam membentuk pilihan, sehingga tidak sedikit individu yang bakat, kemampuan minat, dan hobinya tidak tersalurkan dengan baik.Individu seperti itu tidak mencapai perkembangan secara optimal.Mereka memerlukan bantuan atau bimbingan dari orang-orang dewasa, terutama konselor, dalam menyalurkan potensi dan mengembangkan dirinya.

${ }^{13}$ Ibid, Op., cit , 218 
4. Layanan Bimbingan Belajar; Bimbingan belajar merupakan salah satu bentuk layanan bimbingan yang penting diselenggarakan di sekolah. Pengalaman menunjukkan bahwa kegagalan-kegagalan yang dialami siswa dalam belajar tidak selalu disebabkan oleh kebodohan atau rendahnya inteligensi.Sering kegagalan itu terjadi disebabkan mereka tidak mendapat layanan bimbingan yang memadai.

5. Layanan Konseling Perorangan; Pada bagian-bagian terdahulu konseling telah banyak disebut.Pada bagian ini konseling dimaksudkan sebagai pelayanan khusus dalam hubungan langsung tatap muka antara konselor dengan klien.

6. Layanan Bimbingan dan Konseling Kelompok; Apabila konseling perorangan menunjukkan layanan individu atau klien orang-perorangan, maka bimbingan dan konseling kelompok mengarahkan layanan kepada sekelompok individu.

7. Kegiatan Penunjang; Pelaksanaan berbagai layanan bimbingan dan konseling memerlukan sejumlah kegiatan penunjang. ${ }^{14}$

Menurut Prayitno, Asas-asas yang dimaksudkan adalah asas kerahasiaan, kesukarelaan, keterbukaan, kekinian, kemandirian, kegiatan, kedinamisan, keterpaduan, kenormatifan, keahlian, alih tangan, dan tut wuri handayani.

1. Asas Kerahasiaan; Segala sesuatu yang dibicarakan klien kepada konselor tidak boleh disampaikan kepada orang lain, atau lebih-lebih hal atau keterangan yang tidak boleh atau tidak layak diketahui oleh orang lain.

2. Asas Kesukarelaan; Proses bimbingan dan konseling harus berlangsung atas dasar kesukarelaan, baik dari pihak si terbimbing atau klien maupun dari pihak konselor.

3. Asas Keterbukaan; Dalam pelaksanaan bimbingan konseling sangat diperlukan suasana keterbukaan,baik keterbukaan dari konselor maupun keterbukaan dari klien. Keterbukaan ini bukan sekedar bersedia menerima saran-saran dari luar, malahan lebih dari itu untuk kepentingan pemecahan masalah.

4. AsasKekinian; Masalah individu yang ditanggulangi ialah masalah-masalah yang sedang dirasakan bukan masalah yang sudah lampau, dan juga bukan masalah mungkin akan dialami dimasa yang akan datang.

14 Ibid, Op., cit , 255 
5. Asas Kemandirian; Pelayanan bimbingan dan konseling bertujuan menjadikan klien dapat berdiri sendiri, tergantung pada orang lain atau tergantung pada konselor. Individu yang dibimbing setelah dibantu diharapkan dapat mandiri dengan ciri-ciri pokok mampu:

a. Mengenal diri sendiri dan lingkungan sebagaimana adanya.

b. Menerima diri sendiri dan lingkungan secara positif dan dinamis.

c. Mengambil keputusan untuk dan oleh diri sendiri.

d. Mengarahkan diri sesuai dengan keputusan itu.

e. Mewujudkan diri secara optimal sesuai dengan potensi, minat dan kemampuan-kemampuan yang dimlikinya.

6. Asas Kegiatan; Usaha bimbingan dan konseling tidak akan memberikan buah yang berarti bila klien tidak melakukan sendiri kegiatan dalam mencapai tujuan bimbingan dan konseling.

7. Asas Kedinamisan; Usaha pelayanan bimbingan dan konseling menghendaki terjadinya perubahan pada diri klien, yaitu perubahan tingkah laku ke arah yang lebih baik.

8. Asas Keterpaduan; Pelayanan bimbingan konseling berusaha memadukan sebagai asfek kepribadian yang kalau keadaannya tidak seimbang, serasi dan terpadu justru akan menimbulkan masalah.

9. Asas Kenormatifan; Usaha bimbingan dan konseling tidak boleh bertentangan dengan norma-norma yang berlaku, baik ditinjau dari norma agama, norma adat, norma hukum atau Negara, norma ilmu, maupun kebiasaan sehari-hari.

10. Asas Keahlian; Usaha bimbingan perlu dilakukan asas keahlian secara teratur dan sistematik dengan menggunakan prosudur, teknik dan alat (instrument bimbingan dan konseling) yang memadai.

11. Asas Alih Tangan; Dalam pemberian layanan bimbingan dan konseling asas alih tangan jika konselor sudah mengerahkan segenap kemampuannya untuk membantu individu, namun individu yang bersangkutan belum dapat terbantu sebagaimana yang diharapkan, maka konselor dapat mengirim individu tersebut kepada petugas atau badan yang lebih ahli. 
12. Asas Tut Wuri Handayani; Asas ini menunjukkan suasana umum yang hendaknya tercipta dalam rangka hubungan keseluruhan antara konselor dank lien. Lebihlebih di lingkungan sekolah, asas ini makin dirasakan keperluannya dan bahkan perlu dilengkapi dengan “ing ngarso sung tulodo, ing madiya mangun karso". ${ }^{15}$

Teknik-teknik Bimbingan dan Konseling. Adapun tehnik bimbingan konseling adalah : pertama, Bimbingan Kelompok (Group Guidance); Teknik ini dipergunakan dalam membantu siswa dalam memecahkan masalah-masalah melalui kegiatan kelompok.Artinya masalah itu dirasakan oleh kelompok atau individu sebagai anggota kelompok. Kedua, Konselimg Individual (Individual Konseling); Konseling merupakan salah satu cara pemberian bantuan secara perorangan dan secara langsung. Pemberian bantuan dilaksanakan secara face to face relationship(hubungan lansung muka ke muka, atau hubungan empat mata), antara konselor dan anak (kasus). Biasanya masalah-masalah yang dipecahkan melalui teknik atau cara ini ialah masalahmasalah yang sifatnya pribadi. ${ }^{16}$

\section{Pelanggaran Tata Tertib sekolah}

Istilah pelanggaran menurut kamus Umum Bahasa Indonesia, adalah perbuatan atau perkara melanggar (UU, Hukum dsb). ${ }^{17}$ Sedangkan tata tertib adalah peraturan-peraturan yang harus dituruti.

Pelanggaran adalah perilaku menyimpang untuk melakukan tindakan menurut kehendak sendiri tanpa memperhatikan peraturan yang telah dibuat. Sedangkan pelanggaran menurut Tarmizi adalah tidak terlaksananya peraturan atau tata tertib secara konsisten akan menjadi salah satu penyebab utama terjadinya berbagai bentuk dan kenakalan yang dilakukan siswa, baik yang didalam maupun diluar sekolah. ${ }^{18}$

\footnotetext{
${ }^{15}$ Bambang Ismaya, Bimbingan dan Konseling studi, karir dan keluarga, (Bandung: PT Refika Aditama, 2015), 27

${ }^{16}$ Anas Salhudin, Bimbingan \& Konseling, (Bandung: CV Pustaka Setia, 2010), 96

17 Depdikbud, Kamus Umum Bahasa Indonesia, 1561

${ }^{18}$ Ibid, Op., cit , 1025
} 
Dari definisi di atas dapat disimpulkan bahwa pelanggaran adalah tingkah laku individu atau kelompok yang berprilaku negatif yang dapat mengakibatkan orang lain rugi atas tingkah lakunya tersebut. Dan pengertian tata tertib siswa di sekolah adalah peraturan yang dibuat oleh staf sekolah untuk di patuhi di dalam sekolah guna memberikan kelancaran pendidikan.

Pada saat ini pelanggaran tata tertib sekolah oleh siswa tidak terlepas dari perilaku yang menyimpang, perlu mendapat penanganan dari guru BK agar tidak mengarah ke tindakan yang lebih berbahaya.

Adapun faktor-faktor yang menyebabkan perilaku menyimpang pada remaja antara lain:

1. Faktor-faktor Biologis; Menurut pendekatan biologis, masalah-masalah remaja disebabkan oleh kegagalan dari fungsi-fungsi tubuhnya.Para ilmuan yang menganut pendekatan biologis biasanya berfokus pada faktor otak dan faktor genetik sebagai penyebab timbulnya masalah-masalah remaja.

2. Faktor-faktor Psikologis; Beberapa faktor psikologis yang dianggap sebagai penyebab timbulnya masalah remaja adalah gangguan berfikir, gejolak emosional, proses belajar yang keliru, dan relasi yang bermasalah.

3. Faktor Sosial; Masalah-masalah psikologis yang berkembang pada remaja juga muncul di sebagian besar budaya.Meskipun demikian, frekuensi dan intensitas masalah-masalah tersebut bervariasi antara budaya yang satu dengan budaya yang lain, dimana variasi ini berkaitan dengan aspek-aspek budaya seperti aspek sosial, ekonomi, teknologi, dan agama. ${ }^{19}$

Penerapan Layanan Konseling Pada Siswa Yang Melanggar Tata Tertib Sekolah di Madrasah Aliyah Darunnajah lumajang

Penerapan layanan konseling yang dilakukan oleh guru BK adalah usaha bimbingan yang dilakukan kepada siswa atau sekelompok siswa yang melakukan pelanggaran di sekolah untuk memberikan pemahaman dan saran kepada siswa yang

19 John W. Santrock, Remaja, (Jakarta: Erlangga, 2007), 233 
melakukan pelanggaran di sekolah. Adanya layanan bimbingan di sekolah itu sendiri adalah untuk menangani siswa yang bermasalah dan mempunyai problematika pada siswa itu sendiri.

Melalui layanan konseling diharapkan pelanggaran tata tertib yang dilakukan oleh siswa dapat berkurang. Layanan konseling yang diterapkan oleh guru BK dalam menangani siswa yang melakukan pelanggaran tata tertib di sekolah sebagai berikut:1. Layanan KonselingIndividu;Layanan konseling individu merupakan bentuk layanan bimbingan dan konseling khusus antara peserta didik (klien) dengan konselor dan mendapat layanan langsung tatap muka (secara perorangan) dalam rangka pembahasandan pengentasan permasalahan pribadi yang diderita peserta didik (klien). Konseling individu merupakan bentuk bentuk layanan yang paling utama dalam pelaksanaan fungsi pengentasan masalah klien. Banyak peserta didik yang tidak mau membicarakan masalah atau urusan pribadi mereka dalam diskusi kelas dengan guru. Beberapa dari mereka ragu untuk berbicara didepan kelompokkelompok kecil. Oleh karena itu, konseling individu dalam sekolah tidak terlepas dari psikoterapi, didasarkan pada asumsi bahwa konseli itu akan lebih suka berbicara sendiri dengan seorang konselor.

Adapun tujuan dari layanan konseling individu dibedakan menjadi dua bagian, yaitu:

1. Tujuan umum; Tujuan umum dari layanan konseling individu adalah terentasnya masalah yang dialami oleh klien, apabila masalah klien itu dicirikan sebagai berikut:

a. Sesuatu yang tidak disukai adanya.

b. Sesuatu yang ingin dihilangkan.

c. Sesuatu yang dapat menghambat atau menimbulkan kerugian.

Maka upaya pengentasan masalah klien melalui konseling individu akan mengurangi intensitas ketidaksukaan atas keberadaan sesuatu yang dimaksud atau meniadakan keberadaan sesuatu yang dimaksud atau bisa jadi mengurangi intensitas hambatan kerugian yang ditimbulkan oleh suatu yang dimaksudkan itu. dengan layanan konseling individu beban kliendiringankan, kemampuan klien 
ditingkatkan, potensi klien dikembangkan. Tujuan umum layanan konseling individu adalah pengentasan masalah klien dengan demikian, fungsi pengentasan sangat dominan dalam layanan ini.

2. Tujuan khusus; Tujuan khusus layanan konseling individu dapat dirinci dan secara langsung dikaitkan dengan fungsi-fungsi konseling yang secara menyeluruh diembannya, antara lain:

a. Melalui layanan konseling individu klien memahami seluk-beluk masalah yang dialami secara mendalam dan komperhensif, serta positif dan dinamis (fungsi pemahaman).

b. Pemahaman itu mengarah kepada dikembangkannya persepsi dan sikap serta kegiatan demi terentaskannya secara spsifik masalah yang dialami klien itu (fungsi pengentasan).

c. Pengembangan dan pemeliharaan potensi klien dan berbagai unsur positif yang ada pada dirinya merupakan latar belakang pemahaman dan pengentasan masalah klien dapat dicapai (fungsi pengembangan ataupemeliharaan).

d. Pengembangan atau pemeliharaan potensi dan unsur-unsur positif yang ada pada diri klien, diperkuat oleh terentaskannya masalah, akan merupakan kekuatan bagi tercegah menjalarnya masalah yang sekarangsedang dialami itu, serta diharapkan tercegah pula masalah-masalah baru yang mungkin timbul (fungsi pencegahan).

e. Apabila masalah yang dialami klien menyangkut dilanggarnya hak-hak klien sehingga klien teraniaya dalam kadar tertentu, layanan konseling individu dapat menangani sasaran yang bersifat advokasi (fungsi advokasi). ${ }^{20}$

Layanan KonselingKelompok; Konseling kelompok merupakan salah satu bentuk konseling dengan memanfaatkan kelompok untuk membantu, memberi umpan balik (feedback) dan pengalaman belajar. Konseling kelompok dalam prosesnya menggunakan prinsip-prinsip dinamika kelompok (group dynamic). Konseling kelompok merupakan kelompok terapeutik yang dilaksanakan untuk

20http//mrarda. wordpress. com/2018/05/06/layanan-konseling-individu. 
membantu klien mengatasi masalah yang berhubungan dengan kehidupan seharihari. Konseling kelompok umumnya ditekankan unuk proses remedial dan pencapaian fungsi-fungsi secara optimal. Konseling kelompok mengatasi klien dalam keadaan normal, yaitu tidak sedang mengalami gangguan fungsi-fungsi kepribadian. Pada umumnya konseling diselenggarakan untuk jangka pendek ataumenengah. ${ }^{21}$

Tujuan konseling kelompok antara lain:

1. Melatih siswa agar berani bicara dihadapan orangbanyak Melatih siswa dapat bertoleransi dengan temannya.

2. Mengembangkan bakat dan minatmasing-masing.

3. Mengentaskan permasalahan-permasalahan yang dihadapikelompok.

4. Melatih siswa untuk berani melakukan sharing dalam kelompok.

Tujuan konseling kelompok adalah berkembangnya kemampuan sosialisasi siswa, khususnya kemampuan berkomunikasinya. Melalui konseling kelompok hal-hal yang dapat menghambat atau mengganggu sosialisasi dan komunikasi siswa diungkap dan didinamikakan melalui berbagai teknik, sehingga kemampuan sosialisasi dan berkomunikasi siswa berkembang secara optimal.

Terdapat lima fase proses konseling kelompok antara lain:

1. Pembukaan; Diletakkan dasar bagi pengembangan hubungan antar pribadi (working relationship) yang baik, yang memungkinkan pembicaraan terbuka dan terarah dalam wawancara konseling. Jika konselor dan konseli bertemu untuk pertama kali, waktunya akan lebih lama dan isinya akan berbeda dibandingkan dengan pembukaan saat konseli dan konselor bertemu kembali untuk melanjutkan wawancara yang telah berlangsung sebelumnya.

2. Penjelasan masalah; Konselor mempersilahkan atau mengundang konseli untuk mengungkapkan alam perasaan, alam pikiran kepada konselor secara bebas. Konselor segera merespon pernyataan perasaan atau pikiran konseli dengan teknik yang sesuai, memiliki derajat emosional yang tinggi, semakin membuka dirinya.

21 Latipun, Psikologi Konseling, (Malang: Universitas Muhammadiyah Malang, 2011), 118 
3. Penggalian latar belakangmasalah; Pada fase penggalian latar belakang masalah ini inisiatif ada pihak konselor untuk memperoleh gambarn yang jelas, lengkap dan mendalam tentang masalah konseli. Fase ini disebut dengan analisis kasus, yang dilakukan menurut sistematika tertentu sesuai dengan pendekatan konseling yang diambil. Konselor disini mengambil sikap"ekletik", karena sistematika analisis disesuaikan dengan jenis masalah, taraf perkembangan konseli, dan pengalaman konselor dalam menetapkan konselingtertentu.

4. Penyelesaian masalah; Berdasarkan data setelah diadakan analisis kasus, konselor dan konseli membahas bagaimana persoalan dapat diatasi. Meskipun konseli selama fase ini harus ikut berfikir, memandang dan mempertimbangkan, peran konselor di institusi pendidikan dalam mencari penyelesaian permasalahan pada umumnya lebih besar.

5. Penutup; Mengakhiri proses konseling dapat mengambil bentuk yang agak formal sehingga konselor dan konseli menyadari bahwa hubungan antarpribadi telah usai. Oleh karena itu biasanya konselor mengambil inisiatif dalam memulai fase penutup ini. ${ }^{22}$

Layanan Informasi; Layanan informasi adalah layanan Bimbingan dan Konseling yang memungkinkan peserta didik (klien) menerima dan memahami berbagai informasi (seperti informasi pendidikan dan informasi jabatan) yang dapat digunakan sebagai bahan pertimbangan dan pengambilan keputusan untuk kepentingan peserta didik (klien). Klien tidak hanya peserta didik tetapi bisa juga orang tua atau wali.Layanan informasi bertujuan untuk membekali individu dengan berbagi pengetahuan dan pemahaman tentang berbagai hal yang berguna untuk mengenal diri, merencanakan, dan mengembagkan pola kehodupan sebagai pelajar, anggota keluarga dan masyarakat.

Pemahaman yang diperoleh melalui layanan informasi, digunakan sebagai bahan acuan dalam meningkatkan kegiatan dan prestasi belajar, mengembangkan cita-cita, menyelenggarakan kehidupan sehari-hari dalam mengambil sebuah keputusan.Layanan informasi dapat diselenggarakan melalui ceramah, tanya jawab,

22http// kajianpustaka. com/2018/01/layanan-konseling-kelompok. 
dan diskusi yang dilengkapi dengan peragaan, selebaran, tayangan foto, film atau vidio, kunjungan ke perusahaan-perusahaan. Berbagai nara sumber,baikdari sekolah sendiri atau dari dari sekolah lain, dari lembaga-lembaga pemerintah, maupun dari berbagai kalangan di masyarakat dapat diundang guna memberikan informasi kepada peserta didik. Namun perlu diingat bahwa semua kegiatan hendaknya direncenakan direncanakan secara matang. Layanan informasi dapat dilaksanakan secara individual, klasikal dan ataupun diselenggarakan secara umum. Dapat juga diberikan secara lisan ataupun seperti jurnal, majalah, dan leaflet.

Suatu layanan informasi yang diberikan untuk pemantapan sikap, dan kebiasaan belajar yang efektif dan efisien serta produktif, baik dalam mencari informasi dari berbagai sumber belajar, bersikap terhadap guru, mengembangkan keterampilan belajar, mengerjakan tugas-tugas pelajaran dan menjalani program penilaian hasil belajar. Pengembangan kegiatan belajar meliputi: a. Tugas-tugas perkembangan masa remaja berkenaan dengan pengembangan diri, keterampilan, ilmu pengetahuan, teknologi dankesenian. b. Perlunya pengembangan sikap dan kebiasaan belajar yang baik,aktif dan terprogram, baik belajar mandiri maupunkelompok. c. Kemungkinan timbulnya berbagai masalah belajar danupaya pengetasannya Pengajaran perbaikan danpengayaan. ${ }^{23}$

\section{PENUTUP}

Berdasarkan hasil penelitian terkait dengan penerapan layanan konseling pada siswa yang melanggar tata tertib sekolah, maka peneliti dapat simpulkan bahwa Bentuk-bentuk pelanggaran tata tertib yang dilakukan oleh siswa Madrasah Aliyah Darunnajah lumajang meliputi pelanggaran ringan, yang berupa terlambat masuk sekolah, dan keluar kelas tanpa izin. Pelanggaran sedang, yang berupa membawa HP ke sekolah dan bolos sekolah. dan pelanggaran berat, yang berupa merokok di lingkungan sekolah dan terlibat pencurian. Dari tiga bentuk pelanggaran siswa

${ }^{23}$ http://faddilarahma.blogspot.co.id/2012/11/materi-layanan-informasi. 
tersebut yang paling dominan adalah bentuk pelanggaran ringan, yang berupa datang terlambat kesekolah.

Penerapan layanan konseling yang dilakukan oleh guru BK di sekolah Madrasah Aliyah Darunnajah lumajang dalam menangani kasus siswa yang melakukan pelanggaran tata tertib sekolah yaitu dengan menggunakan layanan konseling individu, layanan konseling kelompok, dan layanan informasi. Dari layanan konseling yang diterapkan tersebut telah memberikan efek posistif dalam mencegah dan mengurangi tingkat pelanggaransiswa.

\section{REFERENSI}

Erie Hariyanto, Carok VS Hukum Pidana Indonesia (ProsesTransformasi Budaya Madura Kedalam Sistem Hukum Indonesia), dalam Karsa, VOL. XII, edisi 2 Oktober, 2007.

Adang Hambali, Ujam Jaenudin, Psikologi Kepribadian, Bandung: CV Pustaka Setia, 2013.

Anas Salhudin, Bimbingan \& Konseling, Bandung: CV Pustaka Setia, 2010.

Andi Hakim Nasution, Pendidikan Agama dan Akhlak Bagi Anak dan Remaja, cet. 1, Ciputat: Logos Wacana IImu,2002

Andy Prastomo, Metode penelitian kualitatif dalam Persfektif Rancnagan Penelitian, Jogjkarata: AR-Ruzz Media, 2012.

Bambang Ismaya, Bimbingan dan Konseling studi, karir dan keluarga, Bandung: PT Refika Aditama, 2015.

Depdikbud, Kamus Umum Bahasa Indonesia, 2004.

Emzir. Metodologi Penelitian Kualitatif Analisis Data, Jakarta: Rajawali pers, 2002.

Husain Umar, Metode Penelitian Untuk Skripsi Dan Tesis Bisnis, Jakarta PT.Raja Grafindo Persada:1996

John W. Santrock, Remaja, Jakarta: Erlangga, 2007.

Juliansyah Noor, Metodologi Penelitian, Jakarta : Kencana Prenada Media Group, 2011. Latipun, Psikologi Konseling, Malang: Universitas Muhammadiyah Malang, 2011.

Mohammad Ali \& Mohammad Asrori, Psikologi Remaja, Perkembangan Peserta Didik, Jakarta: PT Bumi Aksara, 2004. 
Namora Lumongga Lubis, Memahami Dasar-Dasar Konseling, Medan: Kencana Prenada Media Group,2011.

Peter Salim dan Yenny Salim, Kamus Bahasa Indonesia Kontemporer, Jakarta, Modern English Perss,2002.

Prayitno, Erman Amti, Dasar-Dasar Bimbingan dan Konseling, Jakarta: PT.Rineka Cipta, 1994.

Sjarkawi, Pembentukan Kepribadian Anak, Jakarta: PT Bumi Aksara, 2006.

Sugiono. Metode Penelitian Kuantitatif Kualitatif dan R\&D, Bandung: Alfabeta, 2009.

Sukamto, Kenakalan Remaja, Paper Diskusi IImiah, Dosen Sunan Kalijaga Yogyakarta, 2001

Syamsu Yusuf, A. Juntika Nurhisan, Bimbingan dan Konseling, Bandung: PT Remaja Rosdakarya, 2005.

Wardati, Mohammad Jauhar, Implementasi Bimbingan \& Konseling di Sekolah,

Surabaya: Prestasi Pustakarya, 2011. 